\title{
"Concealing" and "revealing" as multimodal strategies in the British and German public service advertising (PSA)
}

\author{
T. V. Tsyliuryk \\ Taras Shevchenko National University of Kyiv, Kyiv, Ukraine \\ Corresponding author. E-mail: tsyliuryk.t@gmail.com \\ Paper received 30.08.20; Accepted for publication 21.09.20.
}

https://doi.org/10.31174/SEND-Ph2020-235VIII70-12

\begin{abstract}
The article reviews the multimodal realization of the "concealing" and "revealing" strategies in the PSA discourse of Great Britain and Germany; the topics and the objects/subjects to be disguised or manifested; as well as the taboo-avoiding or taboo-foregrounding tactics in the PSA of both countries. While a taboo (body images and sexuality) is to be hidden through different advertising tactics, some examples of PSA use an intentional reference to a taboo. Apart from taboo topics, concepts, and violation of social norms, the British and German PSA reveals social and cultural stereotypes, which lead to discrimination in societies.
\end{abstract}

Keywords: public service advertising (PSA) discourse, "concealing" strategy, "revealing" strategy, taboo-avoiding tactics, taboo-foregrounding tactics, shockvertising.

Introduction. In the midst of intense competition and a wide variety of information, advertisers always have to deviate from the established norms. Designers of the ads and copywriters should often opt for new, unique objects and images to get the audience's attention through suspense, shock, novelty, hyperbole, paradox, etc. [26, p. 208; 11]. Hence, the main subject/object of a social problem and its characteristics no longer play a central role in the multimodal text of public service advertising (PSA). Instead, all sorts of seemingly irrelevant content are pushed to the fore in order to make a more indirect, hidden, but recoverable connection to the main subject/object of the social problem $[25$, p. $4 ; 24$, p. $171 ; 29]$. These "concealing" and "revealing" strategies toward the main subject/object of the social problem and its features are the key features of the British and German PSA $[24 ; 10]$.

Brief review of publications on the topic. According to H. Stöckl, the multimodal strategies of "concealing" and "revealing" in the British and German PSA are realized through three interconnected principles, by which the recipient interprets the message of the PSA [24, p. 175-180; 25, p. 10] These are: 1) communicative indirectness - Grice's cooperative principle [14] and implicature theory (pragmatics); 2) secondary meanings of signs - connotation and myth [8] (semiotics); 3) conceptual integration - metonymy and metaphor [19;27; 17; 31] (cognitive semantics).

One of the most distinctive features of the PSA discourse is the extensive use of implicatures [1, p. 74]. Recipients of the ads notice a discrepancy between their real expectations from the ads (their objects and features) and the presented verbal and visual signs. To involve the recipient of PSA in the decoding process, advertisers (the communication source of PSA) deliberately assign implied meaning to the PSA message. Considering this, we can define the notion of implicature in PSA as a decoded intention of the non-verbalized information, the transmission of which is possible as the result of deliberate violation of the Grice's maxims by advertisers [4, p. 68; 1, p. 77]. According to Grice, almost all the tropes flout the maxim of Quality [14, p. 53]. To conclude, inferring sense from the PSA text is only feasible within the context of the ad and the background knowledge of the recipient.

The notions of connotation, myth, and secondary semiotic system support the implicature theory, which gives only an indication of the implied meaning of signs. C. Morris [20] and C. Peirce [22] explained communication as an indirect perception of signs and as the process of production and conveyance of meaning [32, p. 28], as unlimited semiosis. Apart from the literal meaning (denotation), visual and verbal signs of PSA have one more level of interpretation, which depends on the psychological and cultural aspects, personal and emotional associations of the recipient - connotation. Interpretation of a certain sign, in its turn, can serve as the sign for another semiotic chain - secondary semiotic system (the structure of myth by R. Barthes [8, p. 114-115]), which leads to infinite semiotic regress [21, p. 38]. Decoding the message of PSA, we should take into consideration the fact that the informative and communicative potential of the PSA depends not only on the visual and verbal signs in the ad but also on their combination [3, p. 30; 7]. PSA limits the potential of semiosis as, according to their genre and background knowledge, recipients will read the signs in connection with the topic of the ad [24, p. 177$178 ; 25$, p. 10].

H. Stöckl points out the visual richness (image-centricity), semantic ambiguity, pragmatic obscurity, and rhetorically complex structure of the modern PSA posters, defining them as "enigmatic", "en-riddled" advertisements [28; 30]. Contrary to the traditional, linear advertising, signs used in the "enigmatic" ads connect to concepts, which are organized in the domains of knowledge and experience [25, p. 10]. From the cognitive-semantic point of view, the whole PSA can be regarded as a conceptual metaphor or metonymy $[24 ; 19 ; 27$; $17 ; 31]$.

The aim of the research is to review the multimodal realization of the "concealing" and "revealing" strategies in the PSA discourse of Great Britain and Germany; the topics and the objects/subjects to be disguised or manifested; as well as the taboo-avoiding or taboo-foregrounding tactics in the PSA of both countries.

Data and methods. This study builds on a dataset of 70 examples of print and static online PSA in Great Britain and Germany, covering a wide variety of topics and social issues. The dataset includes PSA campaigns by the Federal Centre for Health Education (Germany), Innocence in Danger (Germany), Social-Bee (Germany), the National Health Service (the UK), 28 Too Many (the UK), Kids Company (the UK), the International Society for Human Rights, Save the Children, etc.

The analysis included the methods and the terminology of modern communication, media, and text theory; the combination of the main principles of the cognitive-discursive and linguo-cultural approaches to the study of the PSA discourse of Great Britain and Germany. Contextual, descriptive, and interpretative methods helped identify the topics and the objects/subjects hidden or revealed in the PSA posters of both countries. From the critical discourse analysis and multimodal analysis points of view, the creolized posters of the German and British PSA were considered as visual- 
verbal unities. In light of modern communication tendencies, the article investigated creolization and image-centricity of the PSA posters.

Results and their discussion. Body images and sexuality belong to central, yet tabooed, topics depicted in the British and German PSA discourse [24, p. 182-183; 10]. For example, they find their place in sexual health campaigns and blood donation campaigns. Therefore, designers of PSA often seek balance combining the two opposite strategies of "concealing" and "revealing" when it comes to body images and sexuality in the British and German PSA discourse.

\section{Auch für junges Gemüse!}

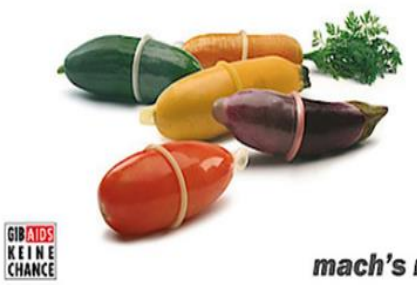

Passt auf jede Gurke!

\section{Ist nicht feige!}

Gegen Kurzsichtigkeit!
For instance, Germany's HIV/AIDS prevention campaign "Gib AIDS keine Chance" (Fig. 1) aims to overcome the taboo of showing a male sexual organ in public. For this purpose, it resorts to visual euphemism [25, p. 23; 2] - images of fruits and vegetables in condoms. Verbally, the taboo is avoided with the help of elliptical sentences and wordplay based on ambiguity, homonymy, and semantic deviation:

"(Kondom ist) Auch für junges Gemüse! Gib AIDS keine Chance. Mach's mit (Kondom)" - "junges Gemüse" - (1) green vegetables; (2) (fig., hum. inf.) youngsters [12];

"(Kondom) Passt auf jede Gurke!" - "die Gurke" - (1) cucumber; (2) (sl.) dick [15];

"(Das) Ist nicht feige!" - "die Feige" (noun) - fig; "feige" (adj.) - coward (using a condom during a sexual act is not cowardice) [9];

"(Kondom/Karotte ist) Gegen Kurzsichtigkeit!" - "die Kurzsichtigkeit" - (1) short-sightedness (carrots are commonly claimed to improve eyesight); (2) imprudence (neglecting protection - condoms - during a sexual act would be imprudent) [18].

The campaign consists of two semantically incongruent fields: fruits/vegetables (visual euphemisms) and a human being (sexual connotation that requires concealing). The unexpected humorous effect is achieved with a sudden semantic shift from one semantic field to the other [5, p. 372]. Designers of the campaign intentionally break the Grice`s maxims of the cooperative principle [14], visually leading the recipient to the incorrect interpretation and replacing the taboo object with visual euphemisms. Using their cultural knowledge and integrating visual and verbal components of the ad, recipients should identify the violation of the cooperative principle and interpret the ad's message correctly in the context of the outlined social problem.

To tackle the same social problem, the PSA campaign "Liebesleben" (Fig. 2) hides sexual connotation in a two-fold manner (verbal and visual) as well. The ad bases its structure on the strength of a verbal metaphor "brennt" (source domain FIRE - target domain BURNING SENSATION) that is duplicated by means of a pictorial hyperbolized metaphor. The visual technique of cartooning (portraying fictional characters of the ad in various everyday situations - a visit to the doctor, extinguishing a fire, a date, etc. - in the form of comics) allows designers to present the problem humorously. Verbally, the taboo is neutralized with euphemisms (wenn`s unten brennt, im Schritt).

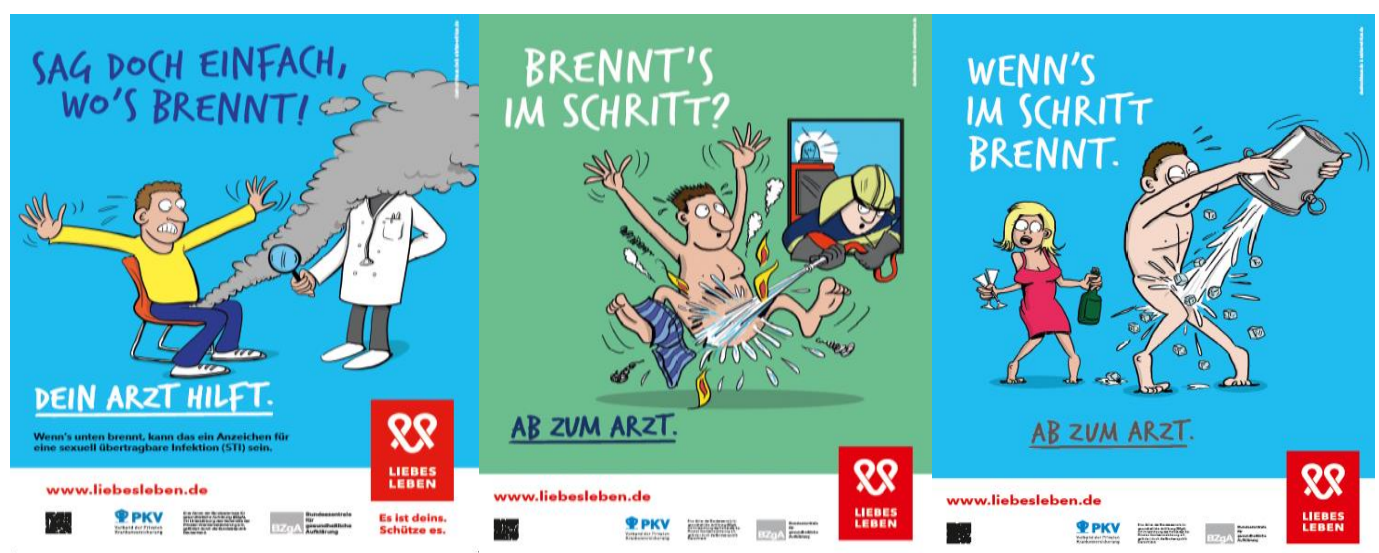

Fig. 2. Liebesleben

In case of the ad that promotes blood donation during the Christmas period (Fig. 3), the "concealing" of blood bags/blood drops is realized through a multimodal metaphor (source domain BLOOD/BLOOD DROP - target domain PRESENT/CHRISTMAS BALL), synecdoche (a blood drop - blood) and metonymy (blood - blood donation): "Give blood. Thank you. Every drop can help make this a happy Christmas for someone". Visual softening of the taboo is due to the blending of concepts in a single gestalt, which is also regarded as a morphing technique [23, p. 24], or a reversible figure [24, p. 190]. By mixing the concepts of BLOOD/BLOOD DROP and PRESENT/CHRISTMAS BALL, designers evoke associations between blood donation and Christmas joy and happiness.

The analysis of the examples above has shown that designers of the British and German PSA succeed in disguising the 
inherent taboo charge of the advertising campaigns (body images and sexuality) while esthetically playing with its provocative potential. To challenge taboos, art directors and copywriters resort to different taboo-avoiding tactics: verbal, visual, and multimodal. A slightly humorous approach helps to de-dramatize a social problem that can be particularly serious for the target audience.

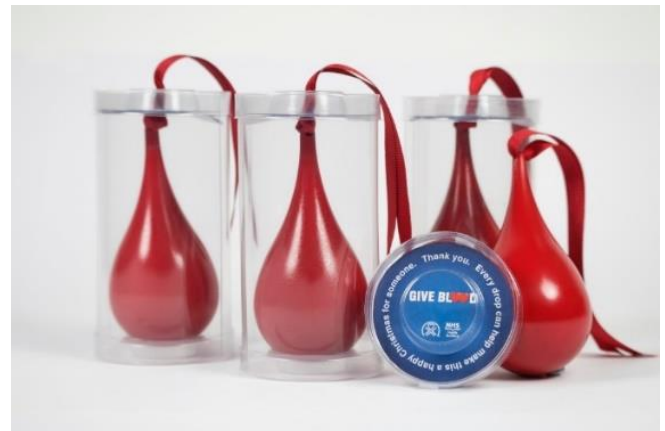

Fig. 3. Give Blood

Opposite to the strategy of "concealing" in the British and German PSA is the strategy of "revealing" [24; 10]. While a taboo is to be hidden through different advertising tactics, some examples of PSA use an intentional reference to a taboo, often breaking the norms [11] and resorting to shock approaches to attract the recipients' attention to central objects of social issues $[13$, p. 12; 10]. This way, the strategy of "revealing", foregrounding taboo, serves the function of provocation, or rather a shock, for a more significant influence on the addressee $[24 ; 25]$.

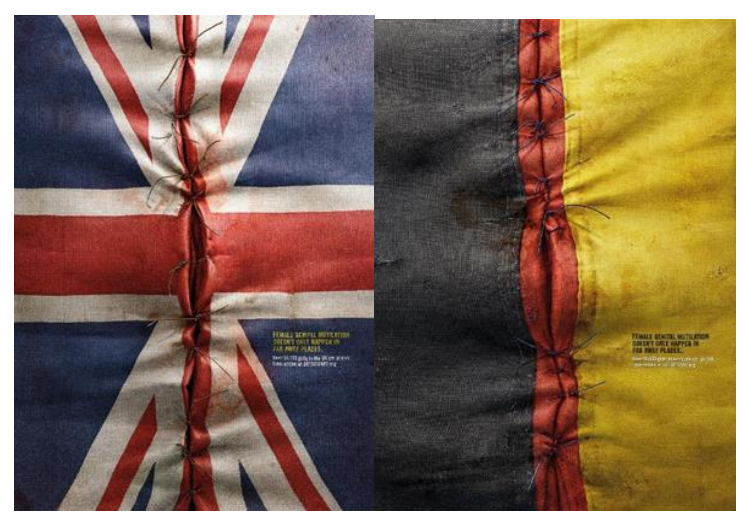

Fig. 4. Female genital mutilation

To illustrate, the British non-commercial campaign against female genital mutilation (FGM) by 28 Too Many (Fig. 4) relies on the shock of its taboo images. The campaign aims to raise awareness about FGM and remind people that the practice is not just occurring in Africa or the Middle East. It is still carried out in countries like the UK or Germany, even though it is illegal. The adverts feature mutilated flags of western countries (such as the Union Jack) splattered with blood stains and stitched back together. This powerful and extremely shocking visual represents a case of FGM: the stitched flags hint on female genitals (visual metaphor, a morphing technique, or a reversible figure). The text printed on the flags supports the visual: "Female genital mutilation doesn 't only happen in far away places. Over 50,000 girls in the UK/Germany are at risk. Take action at 28TOOMANY.org". Country names (the UK/Germany) are used metonymically to refer to the female population at risk and visually correspond to the flags (visual metonymy).

German PSA by the International Society for Human Rights (Fig. 5) initiates the discussion about the death penalty, using visual allusion [2] to the crucifixion of Jesus and typopictoriality [24, p. 190] ("A.D. 2018 End the era of death penalty. Support us on igfm.de") as taboo-enhancing devices.

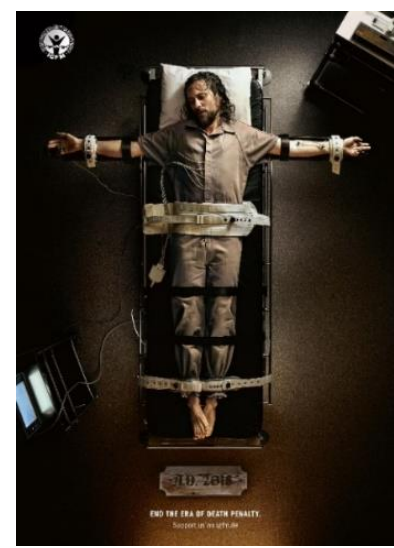

Fig. 5. Death penalty

The same strategy of shockvertising (shock + advertising) is used in the German PSA against online pedocriminals (Fig. 6). The campaign invokes a taboo with the help of visual and verbal depersonification [2] (CHILDREN = SEX TOYS) and verbal metonymy (CHILDREN = INNOCENCE): "750,000 pedocriminals are constantly searching the web for sex toys. Innocence in danger".

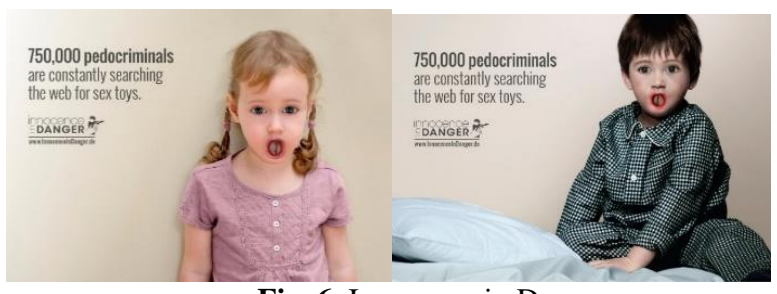

Fig. 6. Innocence in Danger

Visual hyperbole [2] and metaphor (source domain PROTECTION - target domain SIGNATURE) and the instrument-for-action metonymy (SIGNATURE - PEN) are the means of revealing the topic of child abuse in the British PSA (Fig. 7): "Your signature can help protect a child". The exaggerated size of the pen suggests the essential role of a single signature in protecting vulnerable children against domestic violence.

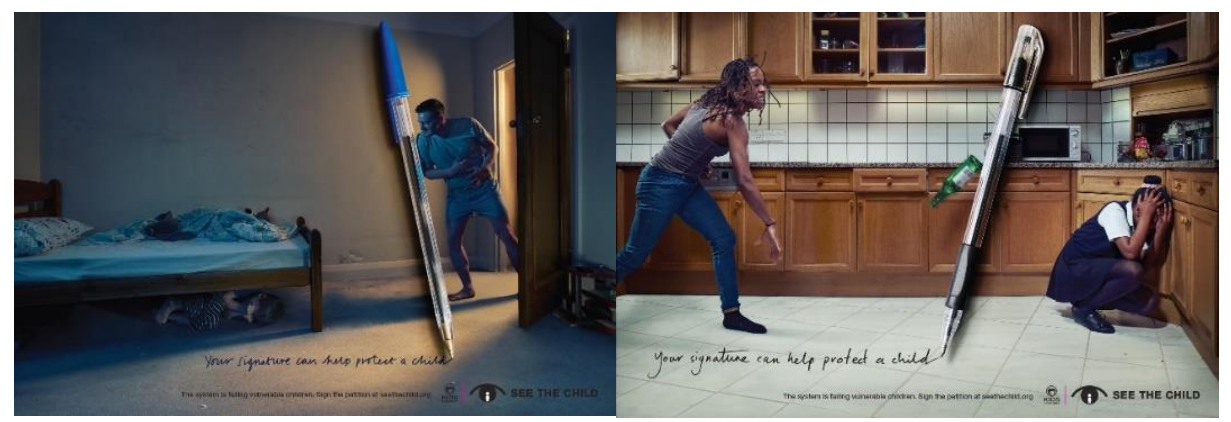

Fig. 7. See the Child - Signature 
Opposite to visual hyperbole is visual litotes. Visual litotes is an intentionally reduced image of a particular object/subject of a social issue aimed to demonstrate the criticality of the depicted social problem and the urgent necessity to deal with its origins [2]. British PSA by Save the Children (Fig. 8) shows a miniature boy`s head in bruises (a victim of child abuse) combined with the body of an adult man suffering from alcoholism - visual litotes. Hence, the ad indirectly conveys the message that the problems of the man have their roots in his abused childhood. The text of the ad contains a reference to an idiom based on the metaphoric transfer TIME=MEDICINE: "Time doesn't heal all wounds. Stop child abuse at home".

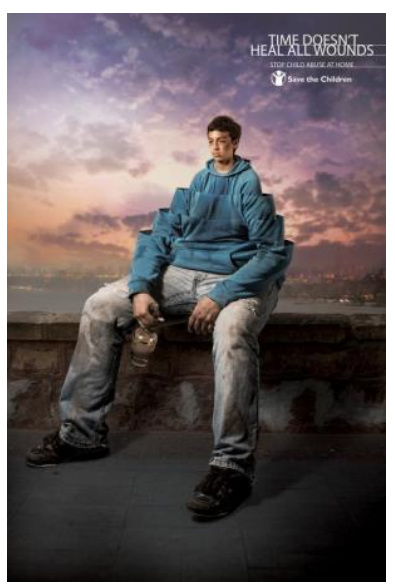

Fig. 8. Save the Children

Apart from taboo topics, concepts, and violation of social norms, the British and German PSA reveals social and cultural stereotypes, which lead to discrimination in the societies [24, p. 186-187]. These stereotypical assumptions, even though hidden in the cultural consciousness, are openly manifested in the PSA discourse of both countries. PSA uses the opportunity to confront the recipient with their social or cultural stereotypes and benefit from the potential for surprise or provocation the revealing of the implied assumptions entails.

Due to migration crisis, racial stereotypes and types of prejudice about refugees take the leading position in the discourse of PSA in Great Britain and Germany [6; 31]. An illustration of this would be the campaign "Spot the refugee. Spot the potential" by Social-Bee (Fig. 9), which promotes the integration of refugees into the German labour market. The campaign is designed to counter the negative representation of refugees as "the others", as losers, victims, and villains [16]. With this purpose, it resorts to the visual and verbal allusion to the famous public figures who fled their native country - Freddie Mercury, Albert Einstein, Marlene Dietrich - and plays with the established stereotypes the recipient might have about refugees. The main characters of the campaign change the attitude towards refugees as losers - they are well-known and successful personalities. The text of the campaign is based on epithets with positive connotations to describe the main characters of the campaign:

"Freddie Mercury was not only an exceptional singer and record producer - but also a refugee. He fled with his family from Zanzibar in 1964 during the revolution";

"Albert Einstein was not only an outstanding physicist and Nobel laureate - but also a refugee. As the child of a secular Jewish family, he fled from Hitler's Third Reich";

"Marlene Dietrich was not only a movie icon and glamorous entertainer - but also a refugee. She fled from Nazi Germany and acquired American citizenship in 1939".

Syntactic parallelism, based on anaphora, emphasizes the fact that refugees are full of potential and encourages employers to provide job opportunities to refugees: "Spot the refugee. Spot the potential. Employ refugees with Social-Bee".
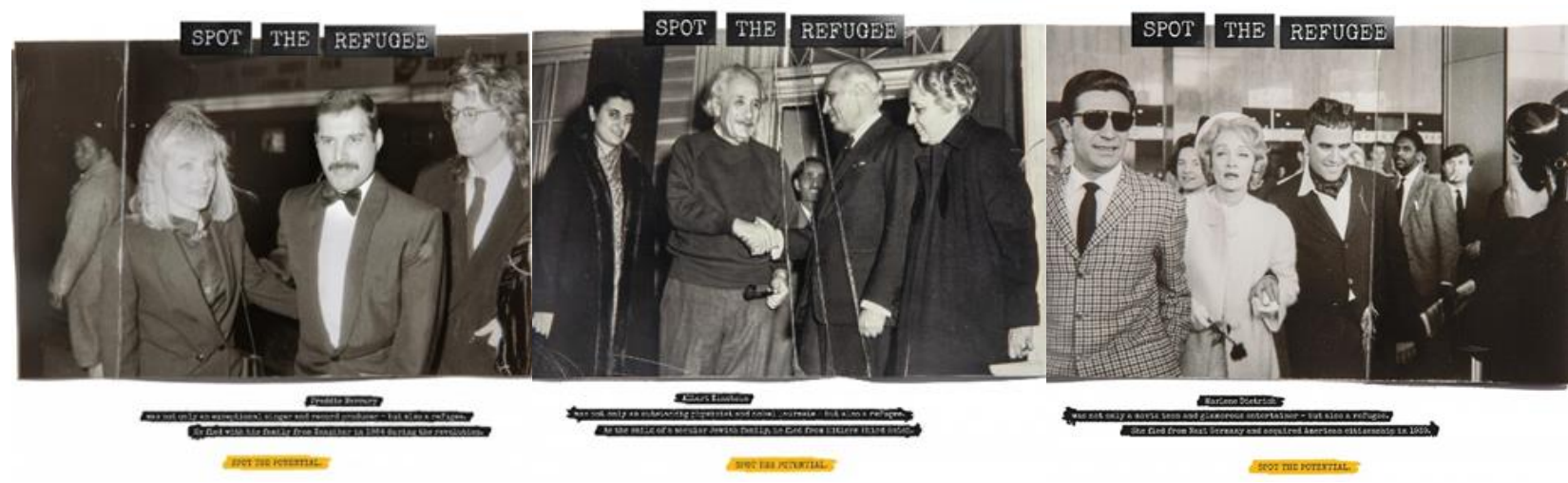

Fig. 9. Spot the Refugee

Conclusions. The results of our research have shown that the multimodal strategies of "concealing" and "revealing" of the main subject/object of the social problem and its features in the British and German PSA are realized through three interconnected principles. These are: 1) communicative indirectness - Grice's cooperative principle and implicature theory (pragmatics); 2) secondary meanings of signs - connotation and myth (semiotics); 3) conceptual integration (cognitive semantics).

The analysis of the examples above has shown that designers of the British and German PSA succeed in disguising the inherent taboo charge of the advertising campaigns (body images and sexuality) while esthetically playing with its provocative potential. A slightly humorous approach helps to dedramatize a social problem that can be particularly serious for those affected by it.
While a taboo is to be hidden through different advertising tactics, some examples of PSA use an intentional reference to a taboo, often breaking the norms and resorting to shock approaches to attract the recipients' attention to central objects of social issues. In addition to violation of social norms and taboo topics, the British and German PSA reveals social and cultural stereotypes, which lead to discrimination in societies. PSA uses the opportunity to confront the recipient with their social or cultural stereotypes and benefit from the potential for surprise or provocation the revealing of the implied assumptions entails. Due to migration crisis, racial stereotypes and types of prejudice about refugees take the leading position in the discourse of PSA in Great Britain and Germany.

The multimodal strategies of "concealing" and "revealing" are realized through different advertising tactics. The most prominent are: pictorial metaphor or metonymy (a morphing 
technique, or a reversible figure), often supported by a verbal metaphor or metonymy; visual hyperbole and litotes; visual and verbal allusion; typopictoriality. Cartooning, visual and verbal euphemisms, elliptical sentences, ambiguity, homonymy, and semantic deviation are common taboo-avoiding tactics.
1. Безугла, Т.А. (2017). Англо- і німецькомовний рекламний дискурс: полікодовий лінгвопрагматичний підхід (Дис. ... канд. філол. наук: 10.02.04). Харків. нац. ун-т. ім. В.Н. Каразіна, Харків, Україна.

2. Каменева В.А., Рабкина Н.В. (2019). Визуальный код рекламы: скрытая суггестия. Политическая лингвистика, 4(76), 83-102.

3. Каратаєва М.В. (2014). Семіотика віртуальної комунікації (Дис. ... канд. філол. наук: 10.02.04). Київський ун-т ім. Т. Шевченка, Київ, Україна.

4. Маслюк М.Г. (2014). Виокремлення типів імплікатур в українській та англійській мовах. Science and Education a New Dimension. Philology, II (7), Issue: 34. 67-70.

5. Самохіна В.О. (2010). Жарт у сучасному комунікативному просторі Великої Британії і США: текстуальний та дискурсивний аспекти (Дис. ... д-ра філолог. наук: 10.02.04). Харків. нац. ун-т. ім. В.Н. Каразіна, Харків, Україна.

6. Цилюрик, Т. (2016). Міграційна криза в соціальній рекламі Великої Британії та Німеччини. Мовні і концептуальні картини світу, 57, 397-403.

7. Цилюрик, Т.В. (2016). Дискурс англійської віртуальної контрреклами як об'єкт лінгвістичних досліджень. Молодий вчений. VIII(35). 313-318.

8. Barthes, R. (1972). Mythologies. London, Cape.

9. Feig/feige. (2020). Duden.de. Retrieved from https://www.duden.de/rechtschreibung/feig.

10. Freitas, E. S. L. (2008). Taboo in advertising. Amsterdam; Philadelphia: John Benjamins Pub. Co.

11. Gaede, W. (2002). Abweichen von der Norm - Enzyklopädie kreativer Werbung. München: Langen Müller/Herbig.

12. Gemüse, das. (2020). Duden.de. Retrieved from https://www.duden.de/rechtschreibung/Gemuese.

13. Goddard, A. (1998). The Language of Advertising: Written Texts. London: Routledge.

14. Grice, H. P. (1975). Logic and Conversation. In: Cole, P. \& Morgan, J.L., (eds.), Syntax and Semantics. Vol. 3: Speech acts. New York: Academic Press, 41-58.

15. Gurke, die. (2020). Duden.de. Retrieved from https://www.duden.de/rechtschreibung/Gurke.

16. Hall, S. (1977). The Spectacle of the "Other". In: Hall, S., (ed.), Representation: Cultural Representations and Signifying Practices, London, Sage/The Open University, p. 223-290.

17. Kövecses, Z. (2002). Metaphor. A practical introduction. Oxford: Oxford University Press.

\section{PATУPA}

18. Kurzsichtigkeit, die. (2020). Duden.de. Retrieved from https://www.duden.de/rechtschreibung/Kurzsichtigkeit.

19. Lakoff, G. \& Johnson, M. (1980/2003). Metaphors we live by. Chicago: University of Chicago Press.

20. Morris, C. (1971). Writings on the general theory of signs. The Hague: Mouton.

21. Nöth, W. (1985). Handbuch der Semiotik. Stuttgart: Metzler.

22. Peirce, C. S. (1998). The essential writings. Edited by Edward C. Moore Amherst, N.Y.: Prometheus Books.

23. Stöckl, H. (2004). In between modes: Language and image in printed media. In: E. Ventola, C. Charles, \& M. Kaltenbacher (Eds.), Perspectives on Multimodality (pp. 9-30). Amsterdam: John Benjamins.

24. Stöckl, H. (2008). Was hat Werbung zu verbergen? Kleine Typologie des Verdeckens. In: Pappert S., \& Schröter, M., Fix, U. (eds.). Verschlüsseln, Verbergen, Verdecken, in öffentlicher und institutioneller Kommunikation. Berlin: Erich Schmidt. 171-196.

25. Stöckl, H. (2009). Beyond Depicting. Language-Image-Links in the Service of Advertising. In: AAA Arbeiten aus Anglistik und Amerikanistik, 34:1. 3-28.

26. Stöckl, H. (2009). The language-image-text - Theoretical and analytical inroads into semiotic complexity. Arbeiten aus Anglistik und Amerikanistik, 34. 203-226.

27. Stöckl, H. (2010). Metaphor revisited: Cognitive-conceptual versus traditional linguistic perspectives. AAA: Arbeiten aus Anglistik und Amerikanistik, 35(2), 189-208.

28. Stöckl, H. (2017). The multimodal enigmatic advertisement: "Enriddling" as a rhetorical strategy in commercial persuasion. In P. Handler, K. Kaindl, \& H. Wochele (Eds.), Ceci n`est pas une festschrift (pp. 69-81). Berlin: Logos.

29. Stöckl, H. (2020). Multimodality and mediality in an image-centric semiosphere - A rationale. In C. Thurlow, C. Dürscheid, \& F. Diémoz (Eds.), Visualizing Digital Discourse: Interactional, Institutional and Ideological Perspectives (pp. 189-202). (Language and Social Life). Berlin: De Gruyter.

30 Stöckl, H., Caple, H., \& Pflaeging, J. (Eds.) (2020). Shifts toward Image-Centricity in Contemporary Multimodal Practices: Insights from Social Semiotic Approaches. London/New York: Routledge.

31 Tsyliuryk, T. V. (2019). Conceptual metaphor in the public service advertising (PSA) discourse on migration crisis and poverty in Great Britain and Germany. Science and Education a New Dimension. Philology, VII (63), Issue: 212. 72-75.

32 Volli, U. (2002). Semiotik. Tübingen/Basel.

\section{REFERENCES}

1. Bezuhla, T. (2017). English and German advertising discourse: polycode linguistic and pragmatic approach $(\mathrm{PhD}$ thesis in Philology). V. N. Karazin National University of Kharkiv, Ukraine.

2. Kameneva, V. A., Rabkina N. V. (2019). The visual code of advertising: covert suggestion. Political Linguistics, 4(76). 83-102.

3. Karataeva, M. (2014). Semiotics of virtual communication ( $\mathrm{PhD}$ thesis in Philology). T. Shevchenko National University of Kyiv, Ukraine.

4. Masliuk, M. (2014). The eduction of the implicature types in the Ukrainian and English languages. Science and Education a New Dimension. Philology, II (7), Issue: 34. 67-70.

5. Samohina, V.O. (2010). The joke in contemporary communicative space of Great Britain and the USA: textual and discursive aspects (PhD thesis in Philology). V. N. Karazin National University of Kharkiv, Ukraine.

6. Tsyliuryk, T.V. (2016). Migration crisis in social advertising of Great Britain and Germany. Linguistic and Conceptual Pictures of the World, 57, 397-403.

7. Tsyliuryk, T.V. (2016). Discourse of English virtual counteradvertising as the object of linguistic research. Young Scientist. VIII(35). 313-318. 